Прегледни научни рад УДК 061.6:811.163.41'243(497.11Ниш)"2013/2020"

Примљен: 31. март 2021.

Прихваћен: 1. април 2021.

Александар М. Новаковић ${ }^{1}$

Универзитет у Нишу

Филозофски факултет ${ }^{2}$

Департмана за србистику

\title{
АКТИВНОСТИ ЦЕНТРА ЗА СРПСКИ КАО СТРАНИ И НЕМАТЕРЫИ ЈЕЗИК ФИЛОЗОФСКОГ ФАКУЛТЕТА УНИВЕРЗИТЕТА У НИШУ ОД ОСНИВАҢА ДО ДАНАС
}

\begin{abstract}
У раду је представљен рад Центра за српски као страни и нематерњи језик при Департману за србистику Филозофског факултета Универзитета у Нишу. Аутор настоји да анализом годишњих извештаја матичне институције објасни начин организације и функционисања Центра, као и да представи остварене резултате ангажованих наставника и сарадника у периоду од његовог оснивања 2013. године до краја 2020. године. Резултати спроведеног истраживања показују да се основна функција Центра реализује кроз разноврсне наставне и ненаставне активности: организацију курсева српског језика као страног, проверу знања, организовање округлих столова, учешће на конференцијама и пројектима и публиковање наставних материјала и научноистраживачких радова. Центар у понуди има чак шест различитих курсева (индивидуалног и групног карактера) и три врсте тестирања, која се могу реализовати у учионици или путем интернета. До данас је кроз просторије Центра прошао сто тридесет и један ученик који је похађао наставу и једанаесторо ученика који су били подвргнути тестирању ради издавања одговарајућег сертификата.
\end{abstract}

Кључне речи: Филозофски факултет Ниш, Центар за српски као страни и нематерњи језик, методика наставе српског као страног језика, наставне активности, ненаставне активности

\section{1. Увод}

Вишевековна историја нашег народа, језика и књижевности сведочи о интересовању странаца да науче српски језик, њим говоре и пишу ${ }^{3}$. У улози њихових наставника нашли су се најумнији појединци

1 aleksandar.novakovic@filfak.ni.ac.rs

2 Рад је настао у оквиру интерног пројекта Србистика на Филозофском факултету у Нишу (бр. 100/1-10-9-01), чији је руководилац проф. др Надежда Јовић.

3 Примера ради, Гете је пре свих осталих превео Хасанагинииу на немачки језик захваљујући добром познавању српског језика. 
- истакнути научници, лингвисти и професори. На основу сопственог искуства и доброг познавања српскога језика проналазили су начине да странце, често своје пријатеље, подуче и олакшају им у настојању да га савладају. Но, први озбиљнији кораци у овој врсти наставе и у установљењу методике наставе српског као страног језика начињени су средином прошлога века, када се објављују прве студије и спроводе прва емпиријска истраживања (в. KRAJIŠNIK 1992). Истраживачи су се учили на грешкама и махом „тајно ослањали на уџбенике страног језика, црпећи идеје, моделе и приступе језичкој материји" (KRAJIŠNIK 2016: 9). У то време српски језик се изучавао (паралелно са другим страним језицима) на Коларчевом народном универзитету, Институту за стране језике и већем броју лектората српскога језика, који се у послератним годинама почињу отварати на иностраним универзитетима (KRAJIŠNIK 2014: 218).

Са оснивањем Центра за српски као страни језик при Филолошком факултету Универзитета у Београду 1987. године започиње ера систематичнијег и организованијег приступа проучавању методике и наставе српског као страног језика. Запослени у центру пажњу усмеравају ка битним теоријским и методолошким питањима ове врсте наставе, те организују, тренутно једини и најпознатији, скуп ове врсте под називом Српски као страни језик у теорији и пракси. До сада је одржан четири пута - 2006, 2010, 2014. и 2018. године, и том приликом су објављена четири зборника, који представљају праве уџбенике (из) методике наставе српског као страног језика. Милка Николић (2020) својом библиографијом научних радова сведочи о повећаном интересовању наставника, истраживача и научника за проучавање ове врло изазовне научне дисциплине. Пратећи реалне потребе изучавања српског као страног језика и остали филолошки (и филозофски) факултети у Републици Србији и Републици Српској оснивају своје центре. Најпре то чини Филозофски факултет у Новом Саду - оснивају Центар за српски језик као страни 2001. године, а његовом покретању претходила је организација Међународне летње школе српског језика, културе и историје (која данас има традиционални карактер). Затим и Филозофски факултет Универзитета у Нишу оснива 2013. године Центар за српски као страни и нематерњи језик, да би исто то учинио током 2015/2016. године и Филолошко-уметнички факултет Универзитета у Крагујевцу. Иако на Филолошком факултету у Бањој Луци нема посебног центра, српски језик као страни се почиње изучавати под окриљем Центра за стране језике.

Вишегодишње искуство наставника у поменутим центрима преточено је у више монографија, приручника и велики број научних радова о чему сведоче поменуте библиографије: Крајишник 1992 и Николић 2020. Научни и истраживачки рад прати велики број активности које се предузимају у оквиру ових центара, о чему запослени воде детаљну евиденцију. Тако, Весна Крајишник и Небојша Маринковић (2002) у свом 
раду описују активности Центра за српски као страни на Филолошком факултету у Београду, док Љиљана Суботић и Исидора Бјелаковић (2007) износе своја искуства рада у Центру за српски као страни на Филозофском факултету у Новом Саду, са посебним нагласком на усклађивању рада са прописаним оквирима Савета Европе и на сарадњи у оквиру међународних пројеката. Пошто је Центар за српски као страни и нематерњи језик Филозофског факултета Универзитета у Нишу навршио осам година постојања, бројни реализовани пројекти и курсеви дозвољавају нам да сагледамо досадашњи рад овога Центра и размотримо могућности његовог будућег развоја. Стога је предмет овога рада представљање рада Центра за српски као страни и нематерњи језик. Циљ нам је да анализирамо начин организације и функционисања Центра, као и да представимо досадашње остварене резултате ангажованих наставника и сарадника на основу анализе годишњих извештаја о раду Филозофског факултета Универзитета у Нишу.

Рад чини шест поглавља. Након уводних разматрања, у другом поглављу је дат кратак историјат Центра од оснивања до данас. У трећем поглављу детаљно су описане наставне активности, док су у четвртом хронолошки поређане и описане остале (ненаставне) у чијој је реализацији учествовао Центар. У петом поглављу дат је попис најважнијих научних публикација његових наставника и сарадника, а у шестом поглављу изведени су најважнији закључци.

\section{2. Историјат Центра од оснивања до данас}

Потреба за оснивањем центра потекла је из чињенице да према граду Нишу као универзитетском и културном центру гравитира цео југоисток Србије, али и велики број страних држављана - пре свега студената на европским програмима размене, али и појединаца који имају приватне и пословне обавезе у Републици Србији. Према подацима из годишњег извештаја Филозофског факултета у Нишу из 2013. године (IZVEŠTAJ 2013: 32), у Нишу је од оснивања универзитета до 2011. године дипломирало преко 1300 студената страног држављанства. Овај податак је само учврстио настојања наставника и сарадника двају тадашњих департмана ${ }^{4}$ (Департмана за српски језик и Департмана за српску

4 Од 1987. године, када је отпочела настава на тада новоформираној Студијској групи за српскохрватски језик и југословенске књижевности, неколико пута је долазило до промене назива ове студијске групе. Најпре је Студијска група за српскохрватски језик и југословенске књижевности прерасла је у Студијску групу за српски језик и књижевност. У оквиру ове групе постојале су две катедре: Катедра за српски језик и Катедра за књижевност. Одлуком Савета Универзитета у Нишу 2008. године поменуте катедре прерасле су у Департмане - Департман за српски језик и Департман за српску и компаративну књижевност. Од 2020. године департмани су се ујединили у јединствену организациону јединицу под називом Департман за србистику. 
и компаративну књижевност) о потреби оснивања Центра, посебно зато што такав центар (у датом тренутку) практично није постојао јужније од Београда. Стога је Центар за српски као страни и нематерњи језик на Филозофском факултету Универзитета у Нишу основан одлуком декана проф. др Горана Максимовића 12. фебруара 2013. године при Департману за српски језик. Првобитни назив центра био је Центар за српски језик као страни, да би одлуком Наставно-научног већа 18. септембра 2013. године био преименован у Центар за српски као страни и нематерњи језик 5 . Центар је током осмогодишњег постојања водило троје наставника Департмана за србистику. За првог управника Центра у периоду од 2013. до 2016. године именована је (тада доц. др) Ирена Цветковић Теофиловић, а посао секретара обављала је Јелена Стошић. Након истека мандата Центром је управљала доц. др Маја Вукић (†), а посао секретара успешно је обављала Ивана Митић у периоду од фебруара 2017. до августа 2019. године. На место управника Центра 28. октобра 2019. године именована је проф. др Надежда Јовић уместо (прерано) преминуле доц. др Маје Вукић. За секретара Центра изабрана је доц. др Александра Јанић уместо доц. др Иване Митић.

Од оснивања до данас Центар је обављао две основне делатности: 1) проверу знања српског језика код страних држављана и издавање одговарајућих сертификата, 2) организовање курсева за српски као страни и нематерњи језик на свим нивоима - од А1 до Ц2 и више споредних делатности: 3) организовање и реализација пројеката од националног и међународног значаја, 4) припрема одговарајућих наставних материјала и 5) публиковање научноистраживачких резултата из области методике наставе српског као страног (и нематерњег) језика. Центар у својој понуди има три категорије курсева: 1) курсеве српског језика као страног у оквиру међууниверзитетске сарадње, 2) курсеве српског језика као страног у оквиру комерцијалне делатности Факултета и 3) курс Српски језик као страни (који похађају студенти у оквиру неког од европских програма размене). У наставним активностима су од оснивања центра до данас учествовали: проф. др Марина Јањић, проф. др Бобан Арсенијевић, проф. др Александра Лончар Раичевић, проф. др Бранимир Станковић, доц. др Александра Јанић, доц. др Ивана Митић, доц. др Јелена Стошић, мср Александар Новаковић, мср Нина Судимац, мср Јанко Ивановић (волонтер) и мср Наташа Спасић (волонтер).

\section{3. Наставне активности Центра од оснивања до данас}

Наставне активности Центра подразумевају организацију и реализацију часова српског као страног језика у оквиру понуде курсева, са

5 Од свог оснивања центар има своју веб-презентацију која је из године у годину унапређивана - 2013, 2014, 2016. и 2019. 
једне стране, односно спровођење различитих врста тестирања, са друге стране. Током осмогодишњег постојања наставу српског језика као страног је, према подацима из годишњих извештаја Филозофског факултета Универзитета у Нишу ${ }^{6}$, похађао укупно 131 страни држављанин. Анализа података је показала да убедљиво највећи број ученика долази из Русије (85), Шпаније (14), Румуније (6), Француске и Грчке (по 5), Албаније (3), Бугарске, Сједињених Америчких Држава и Јапана (по 2). Наравно, кроз курсеве Центра прошли су и ученици (из) осталих европских, азијских и јужноамеричких држава: Швајцарске, Пољске, Немачке, Литваније, Јужне Кореје, Кине и Уругваја (в. графички приказ 1). Захваљујући већем броју ангажованих наставника и сарадника Центар је обезбедио све неопходне услове ради реализације наставе и током јесењег и током пролећног на свих шест нивоа, при чему се запажа да је највећи број кандидата (око 85\%) похађао наставу на почетним нивоима А1 и А2, док је далеко мање кандидата пратио наставу на средњем и напредном нивоу. Кандидати који су похађали наставу на средњем нивоу јесу управо они кандидати који су у Републици Србији боравили дуже од шест месеци и који су успешно савладали садржаје на A1 и А2 нивоу. Такође, највећи број одржаних часова реализован је путем учионичког рада, док је мањи број часова реализован путем Скајпа (и то у 2016. години).

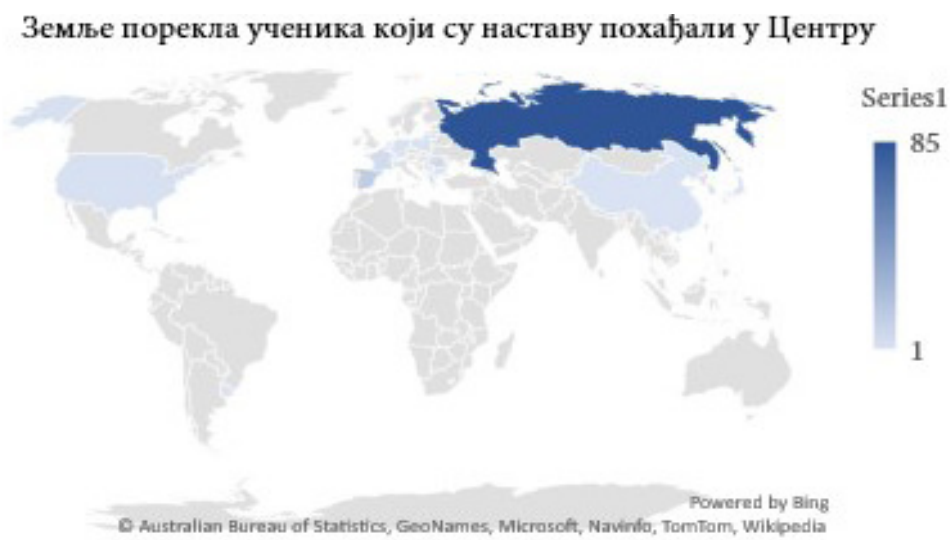

Графички приказ 1. Земље порекла ученика који су наставу похађали у Центру

Све ученике који су похађали часове у оквиру Центра можемо поделити у три велике групе: 1) прву групу чине они ученици који су похађали неки од комерцијалних курсева, 2) другу групу они који су у Републику Србију и Ниш дошли путем европских програма студентске размене и 3) трећу групу чине ученици који су у Центар дошли путем међууниверзитетске сарадње - махом је реч о студентима из Русије који студирају на Државном технолошком универзитету „В. Г. Шухов” из Бел6 Аутор се овом приликом посебно захваљује запосленима у Правној служби Филозофског факултета на помоћи у проналажењу свих потребних извештаја. 
города са којим Универзитет у Нишу има потписан протокол о сарадњи․

Дубља анализа података нам открива да се број кандидата од тренутка оснивања до 2018. године убрзано повећавао. Као најпродуктивнија година се појављује управо 2017, када је чак педесет и троје ученика похађало наставу српског као страног језика. Међутим, током 2019. и 2020. године уочава се пад броја ученика, што се може правдати тиме да су услед појаве пандемије вируса 2019-nCoV замрзнути програми мобилности студената и ограничена путовања страних држављана.

\section{Број кандидата који су похађали наставу по годинама}

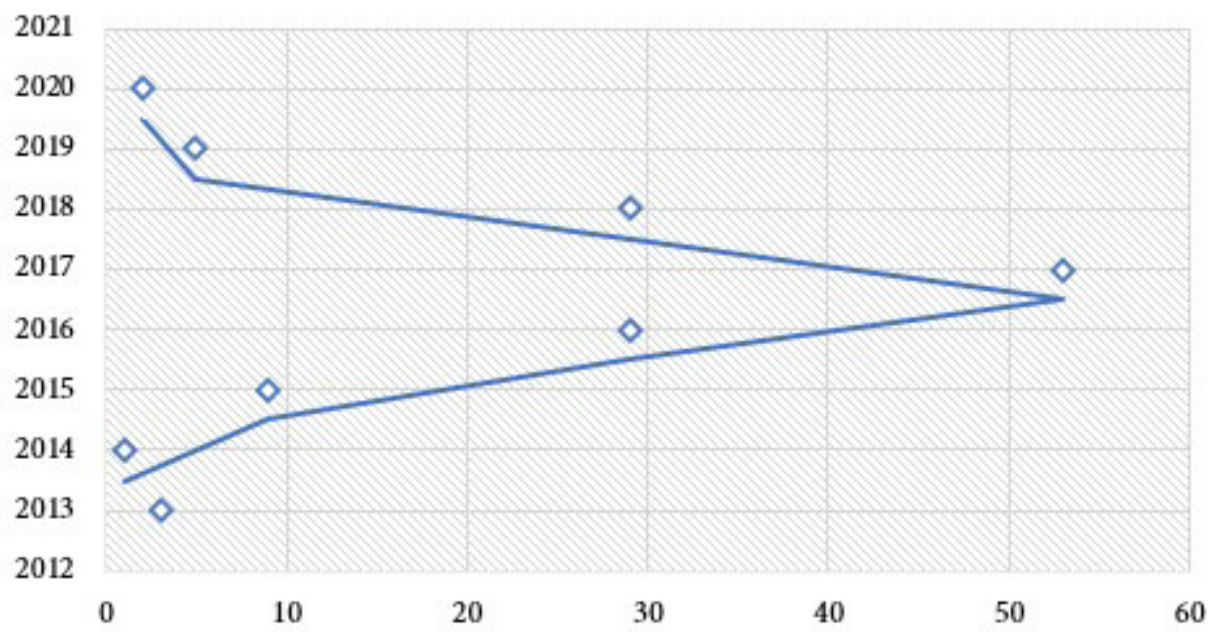

Графички приказ 1. Тренд повећана/сманена броја ученика у Центру од неговог оснивана до 2020. године

Другу важну наставну активност коју предузимају и реализују наставници и сарадници у оквиру рада Центра јесте спровођење тестирања и издавање одговарајућих сертификата, које страни држављани користе ради остваривања одговарајућих личних и пословних потреба. Наиме, уобичајено је да се на почетку средњег и/или високог курса спроводи тзв. улазно тестирање, а на крају курсева завршно тестирање са циљем утврђивања степена савладаности обрађиваних садржаја, односно нивоа развијености комуникативних компетенција ученика. Извештаји показују да ову (другопоменуту) врсту тестова чак 95\% ученика успешно положи. Међутим, Центар у оквиру своје понуде има и комерцијално тестирање - организује се за оне кандидате који наставу српскога језика нису похађали у Центру, али би желели да добију сертификат о познавању језика на одређеном нивоу. До дана данашњег такву врсту тестова успешно је положило једанаесторо кандидата из Бугарске (3), Швајцар-

7 Уговори о сарадњи се могу пронаћи и преузети са веб-адресе Универзитета у Нишу: https://www.ni.ac.rs/saradnja/ugovori-o-saradnji. 
ске (2), Грчке (2), Русије (1), Канаде (1), САД (1) и Македоније (1). Највише тестова ове врсте реализовано је 2015. године, када је чак четворо кандидата затражило организовање ове врсте тестова.

\section{1. Курсеви српског као страног и нематерњег језика}

Центар за српски као страни и нематерњи језик обезбеђује, за све оне који имају потребу и жељу да уче српски језик, реализацију чак шест врста курсева. Реч је о курсевима чији садржаји прате препоруке изнете у Заједничком европском оквиру. Сви се могу поделити у две велике групе: 1) индивидуални курсеви (Индивидуални курс српског језика и Учене српског језика путем Скајпа) и 2) групни курсеви (Почетни курс, Средюи курс, Напредни курс српскога језика и Курс српског језика за студенте на европском програму размене), при чему наставници који реализују наставу настоје да курсеве ове групе индивидуализују тиме што ће у што већој мери пратити жеље, потребе и могућности својих ученика. Заинтересовани ученици се за неки од наведених курсева пријављују кроз неколико врло једноставних корака. У првом кораку контактирају са управником или секретаром Центра (имејлом, путем онлајн пријавног формулара или доласком на Факултет). Том приликом управник, секретар и изабрани наставник спроводе кратку анкету у вези са интересовањима ученика и реалним потребама. Пре него што се ученик одлучи за одређени курс, у другом кораку се реализује улазно тестирање ${ }^{8}$, како би се сагледало реално знање српског језика оних кандидата који су раније већ учили српски језик9. Када кандидат (обично на лицу места) добије повратну информацију, у договору са управником Центра бира одговарајући курс $^{10}$. Према правилу, курсеви почињу са почетком јесењег, односно пролећног семестра, а у одређеним ситуацијама (а према претходном договору са кандидатом и управом Факултета) могу бити реализовани и у току академске године (с посебном напоменом да се током годишњег одмора настава у центру не реализује).

Почетни курс српског као страног језика

Почетни курс српског као страног језика организован је кроз два нивоа - A1 и A2. Ниво A1 је намењен апсолутним почетницима и има за циљ разликовање и савладавање свих фонема српског језика, употребу ћирилице и латинице, односно овладавање основним начелима граматике српскога језика (основних глаголских времена - презента, футура и перфекта, променљивих врста речи и њихових облика - падежи и

8 О овој активности у Центру за српски као страни и нематерњи језик касније ће бити више речи.

9 Уколико кандидат никада раније није учио језик, овај корак се прескаче.

10 Том приликом кандидат добија потврду којом у Полицијској управи правда свој продужени боравак у Републици Србији. 
конгруенција). На нивоу А2 ученици утврђују, продубљују и проширују своја знања, при чему се посебна пажња усмерава на падежни и глаголски систем (те се изучавају императив, трпни глаголски придев), систем непроменљивих речи, као и ред речи у реченици (са посебним освртом на положај енклитика).

Предвиђено време трајања курса је читав семестар, односно двеста двадесет и пет часова. Врло често наставници (према претходном договору са учеником) организују и одрже петнаест часова недељно, како би курс окончали до завршетка текућег семестра. Уколико се из објективних околности (каква је појава пандемије) курс не реализује до завршетка семестра, наставник и ученици курс окончавају са почетком новог семестра. Наставне материјале чине: 1) уџбеници српског језика за почетни ниво (о којима ће више речи бити у наредном поглављу) и 2) материјали самих наставника креирани према интересовањима и потребама ученика.

Средни курс српског као страног језика

Средњи курс српског језика (као странога) организован је на идентичан начин, тј. по истом моделу као и почетни курс српскога језика - ниво Б1 и ниво Б2. Курс је намењен полазницима који имају знања на нивоу А2, односно оним полазницима који су на разврставајућем тесту показали завидан ниво познавања језика. Циљ овога курса је овладавање језичким вештинама (читањем, писањем, слушањем и говором), сложенијим граматичким и лексичким садржајима ради успостављања самосталне комуникације и обављања свакодневних животних активности. На нивоу Б1 се посебна пажња усмерава на обраду футура II, потенцијала, глаголског прилога садашњег и прошлог, апстрактних и глаголских именица. На нивоу Б2 садржаји се утврђују и проширују знањима из области прозодије (места књижевног акцента у речима, разликовањем интонације и дужине акцената), морфологије и основа синтаксе српскога језика.

За разлику од курса за учење српскога на почетном нивоу, курсеви средњег нивоа обухватају фонд од 135 часова. Успешна реализација курса током једног семестра подразумева најмање девет часова недељно. Поред прописаних уџбеника и личних материјала наставника који се употребљавају на часу, врло често се рад заснива и на анализи грешака ученика (како кроз разговор тако и кроз корекцију њиховог писменог изражавања).

Напредни курс српског као страног језика

Иако пракса показује да најмањи број кандидата похађа наставу на напредном нивоу, Центар има разрађен курс, кроз који је до данас прошло више кандидата. Курс је намењен онима који знају српски на 
нивоу Б2. Намењен је ученицима који имају потребу да унапреде своје језичке вештине ради успостављања темељније комуникације са матерњим говорницима српскога језика. Подразумева шире упознавање комплексних језичких образаца и обогаћивање лексичког система српскога језика. На нивоу Ц1 ученици савладавају сложеније фонетско-фонолошке, морфолошке и синтаксичке језичке јединице, а посебна пажња се посвећује разговору о различитим темама, при чему се настоји да након реализованог курса кандидат може да заступа и брани сопствене ставове. Ниво Ц2 је намењен оним говорницима српскога језика који су више година провели у српским срединама и који продукују језичке обрасце на готово истоветан начин на који то чине матерњи говорници. Пракса показује да таквих кандидата нема много, а Центар се може похвалити да је кроз овај курс прошао кандидат В. П., ученик из Русије. Посебна пажња се, поред фонетско-фонолошких, морфолошких, синтаксичких садржаја, посвећује лексичким садржајима стандардног српског језика, као и српских дијалеката (од Шар-планине до Суботице, односно од Јадранског мора до источне Србије).

Курс се реализује током сто тридесет и пет часова; у просеку осам или девет часова недељно. Рад подразумева употребу јединог уџбеника за учење српског као страног на напредном нивоу (Суnер српски, Азбукум), односно коришћење материјала самог наставника који наставу организује и изводи. Такође, велика пажња се посвећује примени савремених комуникативних метода и приступа, којима се странцима олакшава разумевање комплексног граматичког система српскога језика.

Индивидуални курс и Курс српског језика као страног путем Скајпа

Реч је о индивидуалним курсевима српскога језика који се реализују у Центру. Оба курса могу бити организована ради савладавања језика на Заједничким европским оквиром прописаних шест нивоа - од A1 до Ц2. Почетку курса претходи улазно тестирање ради утврђивања нивоа знања, након чега се кандидат и изабрани наставник договарају у вези са терминима и начином реализације часова. Индивидуални курс је додат понуди Центра 2014. године одлуком стручног Већа. Намењен је свима који због природе посла којим се баве или из личних разлога наставу не могу да прате у групи, те га одликује флексибилност у погледу избора термина и садржаја који ће се обрађивати и изучавати. Курс српскога језика путем Скајпа се од поменутог индивидуалног курса ни по чему не разликује, осим по начину његове организације и реализације. До 2019. године часови у оквиру овог курса реализовани су путем апликације Скајп, али са развојем платформи за успостављање виртуелних учионица (Hangouts Meet, Zoom, Microsoft Teams) промењен је и медијум за његово извођење, при чему је настава добила на интерактивности захваљујући већем броју интегрисаних алата које наставници могу кори- 
стити на својим часовима - бела табла, инстант-упитник, функција дељења екрана, односно примена већег броја онлајн апликативних софтвера за образовање.

Разлика између два поменута курса односи се на фонд часова који су предвиђени одговарајућим одлукама Центра и Филозофског факултета. Индивидуални курс подразумева организацију и реализацију оног броја часова који кандидат (у договору са наставником) процени да му је довољан ради полагања теста и добијања сертификата, односно ради побољшања комуникативних компетенција. Курс српскога језика путем Скајпа подразумева фонд од укупно 36 часова, с обзиром на то да је прописано да током његовог трајања наставник мора да одржи дванаест часова месечно, тј. три часа недељно. С обзиром на чињеницу да се кандидати одлучују за ове курсеве ради испуњења својих жеља и потреба, поред поменутих уџбеника, рад на часовима се врло често заснива на примени материјала прилагођених самим ученицима.

Курс српског језика за студенте на европском програму размене

С обзиром на све интензивнију размену студената у којој учествује Универзитет у Нишу, тј. на све већи број страних студената заинтересованих за курс српског језика као страног који би био део њиховог уговора о учењу (енг. learning agreement), у оквиру Центра покренут је курс Српски језик као страни. На седници Наставно-научног већа Филозофског факултета одржаној 6. децембра 2017. прихваћен је предлог да се курс Српски језик као страни уврсти у силабус ОАС Педагогије као изборни курс са 4 ЕСП бодова (IZVEŠTAJ 2017). Курс је намењен студентима који током образовања нису учили српски језик (као матерњи, нематерњи или страни) и предвиђени фонд часова је 60 (2 часа предавања и 2 часа вежби седмично). Циљ курса је да код студената развије компетенције у области усмене и писане комуникације на одређеном нивоу ради праћења наставе на различитим факултетима Универзитета у Нишу. Силабус курса израдили су доц. др Маја Вукић и проф. др Бранимир Станковић, а часови вежби поверени су Александру Новаковићу.

\section{2. Тестирање у оквиру Центра за српски као страни језик}

Како смо већ раније нагласили, реализацију наставе у оквиру Центра за српски као страни језик прати тестирање кандидата као неизоставна и прекопотребна активност. Реч је о две (главне) врсте тестирања које наставници и сарадници у Центру реализују у складу са објективним потребама.

Прву врсту тестова чине улазни тестови, који подразумевају проверу нивоа знања кандидата пре почетка курса, како би ученици похађали одговарајућу врсту наставе, односно како би управник Центра могао да формира хомогене групе. Од оснивања Центра до средине 2020. 
године ова врста тестирања обављала се путем унапред припремљених улазних тестова, које су креирали и проверили њихову функционалност у пракси наставници и сарадници Центра. Како Центар успоставља сарадњу са осталим организационим јединицама на Филозофском факултету, те неминовно и Центром за стране језике, наставник Центра Александар Новаковић је са колегом Николом Татаром креирао онлајн разврставајући тест (под називом Test Your Serbian), који је у првој фази тестирања показао високу тачност (NOVAKOVIĆ, TATAR 2021). Реч је о тесту који је створен по угледу на онлајн тест Универзитета у Кембриџу, а за који су аутори створили сопствени сложени алгоритам и програмирали га за покретање на свим врстама уређаја - рачунарима, таблетима и мобилним телефонима. Резултате свога рада објавили су у педесет и трећој свесци часописа Баштина 2021. године и од тог тренутка се ова врста тестирања (према потреби) реализује кроз његову примену. Аутори су са̂м тест поставили на сервер Филозофског факултета Универзитета у Нишу, тако да му се може приступити из било ког дела света путем вебадресе: http://skr.rs/zz6A.

Другу врсту тестова чине завршни (финални) тестови, који се предузимају ради провере савладаности садржаја и развијености језичких компетенција након курсева. Водећи рачуна о захтевима изнетим у Заједничком европском референтном оквиру за учење језика и обрађеним садржајима, наставници и сарадници Центра креирају тестове за сваког ученика, односно за сваки курс и сваки испитни рок, при чему процес стварања тестова пролази кроз више фаза: креирање теста, проверу његове тачности и прилагођености одређеном нивоу знања и кориговање нефункционалних делова. Ова врста тестирања реализује се кроз више корака и подразумева: 1) проверу вештине писања кроз диктат, 2) проверу граматичких и лексичких знања и 3) проверу комуникативних компетенција ученика кроз конверзацију ученика и наставника. Реализација ове врсте тестирања представља природан завршетак неког од горепоменутих курсева, при чему кандидати немају додатних трошкова (за организацију и издавање одговарајућег сертификата). Међутим, кандидати који нису претходно похађали курс у оквиру понуде Центра, могу такође бити подвргнути тестирању (уз одређену надокнаду); уколико положе, добијају сертификат који могу искористити ради студирања или обављања личних потреба. Том приликом Веће Центра именује комисију, чији су чланови из редова наставног особља, која саставља тест, организује тестирање, оцењује и доноси закључак о испуњености услова за издавање потребне потврде. Комисију су до 2019. године чиниле проф. др Надежда Јовић, проф. др Александра Лончар Раичевић, доц. др Александра Јанић. Од 2019. године састав комисије за проверу знања српског језика као страног чине: доц. др Татјана Трајковић, председник, проф. др Ирена Цветковић Теофиловић, замена, др Ивана Митић, члан и мср 
Нина Судимац, замена.

3.3. Листа уџбеника и приручника који се користе у настави

На званичном веб-сајту Центра за српски као страни и нематерњи језик могу се пронаћи основне информације о уџбеницима и приручницима који се користе у настави. Ради реализације курса на одређеном нивоу употребљавају се они за које наставник у датом тренутку процени да могу донети највише користи ученицима, сходно квалитету уџбеника и реалним потребама ученика. Иако је листа уџбеника дуга, најчешће се употребљавају уџбеници које је Александар Новаковић (2020) у својој дисертацији окарактерисао као „уџбеници на корак до полифункционалности" - Реч по реч (почетни ниво), Више од речи (средњи ниво), Супер српски (напредни ниво). Но, званично се у Центру употребљавају следећи уџбеници, јер наставници и сарадници настоје да паралелном употребом уџбеника надоместе њихове недостатке:

Уибеници за учене српског језика на почетном нивоу

1) БАБИТ 1991: Babić, S. (1991). Serbo-Croatian for Foreigners, Book 1. Beograd: Kolarčev narodni univerzitet.

2) БЈЕЛАКОВИЋ, ВОЈНОВИЋ 2004: Бјелаковић, И., Војновић, Ј. (2004). Научимо српски. Нови Сад: Универзитет у Новом Саду.

3) ДАНИЛОВИЋ 2014: Danilović, М. (2014). Step by Step Serbian. Beograd: Kornet.

4) ИВАНОВА 2003: Иванова, И. Е. (2003). Сербский язык для начинаюших: Учебник и разговорник. М.: Айриспресс.

5) JАЊИТ 2016: Janjić, M. (2016). Serbian for Beginners. Niš: Filozofski fakultet.

6) ЈОКАНОВИЋ-МИХАЈЛОВ, ЛОМПАР 2001: Јокановић-Михајлов, Ј., Ломпар, В. (2001). Говоримо српски: уцбеник српског језика за страние. Београд: Међународни славистички центар.

7) КИШ 2017: Kiš, J. (2017). Step into Serbian. Beograd: Službeni glasnik.

8) МАГНЕР 1998: Magner, Т. (1998). Introduction to the Croatian and Serbian Language. Pennsylvania: The Pennsylvania State University Press.

9) МИЛИЋЕВИЋ-ДОБРОМИРОВ, НОВКОВИЋ 2009: Милићевић-Добромиров, Н., Новковић, Б. (2009). Учимо српски 1. Нови Сад: Центар Азбукум.

10) РИБНИКАР, НОРИС 2003: Ribnikar, V., Norris, D. (2003). Teach Yourself - Serbian. Great Britain: Hodder Headline.

11) СЕЛИМОВИЋ-МОМЧИЛОВИЋ, ЖИВАНИЋ 2012: Селимовић-Момичиловић, М., Живанић, Љ. (2012). Српски језик за страние - почетни курс. Београд: Институт за стране језике.

12) ЋОРИЋ 1998: Ćorić, В. (1998). Srpski jezik za strance. Beograd: MSC. 
13) ЋОРИЋ 2002: Ћорић, Б. (2002). Српски језик за странще. Београд: Чигоја штампа.

14) ЋОСИЋ 2004: Ћосић, П. (2004). Приручник за лекторе и студенте српског као страног језика. Познањ: WN UAM.

Уибеници за учеюе језика на средюем нивоу

1) АЛАНОВИТ И САР. 2006: Алановић, М., Бјелаковић, И., Бугарски, Н., Дражић, Ј., Курешевић, М., Војновић J. (2006). Научимо српски 2. Нови Сад: Универзитет у Новом Саду.

2) ЗДРАВКОВИЋ И САР. 2012: Здравковић, С., Живанић, Љ., Путник, Б. (2012). Српски за странще 2: Вище од речи, Београд: Институт за стране језике.

3) МИЛИЋЕВИЋ-ДОБРОМИРОВ И САР. 2006: Милићевић-Добромиров, Н., Ћук, Љ., Радуловић, Н. (2006). Учимо српски 2. Нови Сад: Центар Азбукум и Љубитељи књиге.

Уибеници за учење српског језика на напредном нивоу

1) МИЛИЋЕВИЋ ДОБРОМИРОВ, НОВКОВИЋ АЏАИП 2016: Милићевић Добромиров, Н., Новковић Аџаип, Б. (2016). Супер српски - високи ниво. Нови Сад: Азбукум.

Како би своје часове осавременили, а наставу учинили ефикаснијом, наставници и сарадници користе приручнике, о којима су раније писали Ђорђе Оташевић у свом раду Приручници за наставу српског језика као страног (2014), односно Кристина Ђорђевић у свом раду Уибеници и приручници српског језика као страног (2018). Реч је о приручницима чији су аутори професори српског као страног језика са дугогодишњим искуством: 1) Весна Крајишник Научимо падеже (1998), 2) Павле Ћосић Српски за странце - тестови, вежбағьа, игре (2004), 3) Јасмина Дражић Минималне лексичке и граматичке структуре у српском као страном језику (2008), 4) Весна Крајишник и Небојша Маринковић Тестови за полагаюе српског као страног (2009), 5) Јелица Јокановић-Михајлов Лекторске вежбе: приручник за српски језик као страни (2010), 6) Весна Крајишник Лексички приступ српском као страном језику (2016), 7) Марина Јањић Методика наставе српског као завичајног језика (2018). Наравно, листи се прикључују и две граматике за странце идентичног назива - Граматика српског језика за странце, које су написали Иван Клајн (2005), односно Павица Мразовић (2009).

4. Остале активности Центра за српски језик као страни од оснивања до данас

Наставници и сарадници Центра су током његовог осмогоди- 
шњег постојања учествовали у реализацији бројних (не)наставних активности, у циљу промоције науке, сопственог рада и наставно-научног кадра.

\section{Остале активности иентра током 2013. године}

Током 2013. године Центар за српски као страни и нематерњи језик учествовао је у реализацији неколико стручних усавршавања и пројеката. У сарадњи са ОЕБС-ом и амбасадом Савезне Републике Немачке организован је седмодневни припремни семинар (у периоду од 19. до 25. августа 2013) за свршене студенте српског језика и књижевности под називом „Српски језик као нематерњи у теорији и пракси”.

Остале активности центра током 2014. године

Центар је у току 2014. године у сарадњи са Канцеларијом за сарадњу са дијаспором учествовао у реализацији пројекта „Бесплатни тромесечни курс српског језика преко Скајпа"11. Како би допринели неговању и очувању српског језика и традиције међу нашим исељеницима, свршени студенти Србистике, студенти мастер и докторских студија Филологије на Филозофском факултету у Нишу држали су два пута недељно у трајању од четрдесет и пет минута часове српскога језика путем Скајпа младима у српској дијаспори ${ }^{12}$. На конкурс ради учешћа у пројекту пријавило се преко шездесет кандидата, а одабрано је двадесет и четири млађег узраста - из САД, Канаде, Немачке, Норвешке, Француске, Велике Британије, Чешке, Грчке, Мађарске, Италије, Аустрије, Уједињених Арапски Емирата, Шпаније.

Исте године Центар је коауторским рефератом „Специфичност методике наставе српског језика као завичајног” (Марина Јањић и Ирена Цветковић Теофиловић) посебно представљен и промовисан на округлом столу „Српска језичка дијаспора: одржавање језика и идентитета говорника у мигранским условима", који је одржан у оквиру IX међународног научног скупа Српски језик, книжевност, уметност у Крагујевцу 24-25. октобра 2014. године.

Остале активности иентра током 2015. године

Посебно важна активност током 2015. године јесте наставак сарадње са Канцеларијом за дијаспору у оквиру пројекта очувања српског језика у дијаспори под називом „Да те цео свет разуме”13. Пројект је реа-

11 Курс је био реализован у периоду од 15. септембра до 15. децембра 2014.

12 Пре званичног почетка наставе крајем фебруара месеца предавачи су прошли методичку обуку на Филозофском факултету у Нишу у трајању од 15 школских часова под руководством проф. др Марине Јањић.

13 Курс је био реализован у периоду од 23. марта 2015. до 20. јуна 2015. 
лизован уз подршку организације „Проактив” и Управе за сарадњу с дијаспором и Србима у региону Министарства спољних послова Републике Србије. На овај конкурс пријавило се преко педесет кандидата из петнаест земаља света, при чему је, у односу на претходно организовани курс, повећан број учесника на тридесет и шесторо (од којих је тридесет и троје успешно савладало садржаје) - из Грчке и САД (по 7), из Велике Британије (6), из Норвешке (5), из Венецуеле (3), Мађарске и Аустрије (по 2) и из Италије, Немачке, Данске и Холандије (по 1 кандидат). Недуго затим су Канцеларија за сарадњу са дијаспором Службе за послове градоначелника града Ниша, Филозофски факултет Универзитета у Нишу и „Медиа и реформ центар” Ниш, под покровитељством Управе за сарадњу с дијаспором и Србима у региону Министарства спољних послова Републике Србије, организовали у периоду од 15. до 17. маја 2015. године конференцију стваралаца из дијаспоре и матице на тему: „Очување језика, културе и идентитета и јачање положаја Срба у дијаспори”. Циљ конференције је био повећање видљивости српских стваралаца у дијаспори и јачање њиховог положаја у заједницама у којима живе и раде, а на конференцији је у својству модератора учествовала др Ирена Цветковић Теофиловић, тадашњи управник центра.

Такође, исте године наставници и сарадници су учествовали у пројекту „Развој општих стандарда постигнућа за српски као нематерњи језик за крај првог, другог и трећег циклуса образовања" у сарадњи са Заводом за вредновање квалитета образовања и васпитања.

Остале активности иентра током 2016. године

Током 2016. године наставници и сарадници Центра учествовали су у реализацији пет веома важних активности. Прву активност представља учествовање у трећем по реду циклусу учења српског језика путем Скајпа за омладину из дијаспоре под називом „Да те цео свет разуме 3 "14. На овај конкурс се пријавило више од четрдесет кандидата, а одабрано је двадесет и осморо из читавог света - из Грчке (11), из Велике Британије (3), из Норвешке, Немачке, Француске и Пољске (по 2) и из Италије и Канаде (по 1 кандидат), односно Аустралије (4 кандидата).

Другу активност представља учешће у реализацији пројекта „Развој општих стандарда постигнућа за српски као нематерњи језик за крај првог, другог и трећег циклуса образовања”. Реч је о завршном делу пројекта, који је реализован у периоду од јануара до јуна 2016. године. Наставници и сарадници су директно учествовали у дефинисању финалне верзије стандарда.

Трећу активност чини креирање силабуса курса Српски језик као страни, који би требало да олакша студентима на размени учење српског језика и његово полагање (више речи о томе ће бити у поглављу о актуел-

14 Курс је био реализован у периоду од 5. марта 2016. до 31. маја 2016. 
ним курсевима у понуди Центра).

Четврту активност током 2016. године представља учешће на семинару. Наиме, наставници и сарадници Центра за српски језик као страни и нематерњи (Снежана Божић, Маја Вукић, Бранимир Станковић, Ивана Митић, Александар Новаковић, Нина Судимац) учествовали су 23. фебруара 2017. године у раду семинара „Education of refugee and migrant children - Second language acquisition and comprehensive school support”, чији је организатор била Канцеларија УНИЦЕФ-а у Београду. На семинару се дискутовало о питањима имплементације деце избеглица и миграната у школски систем у Републици Србији.

Пету активност представља учешће у пројекту „Fostering University Support Services and Procedures for Full Participation in the European Higher Education Area - FUSE", при чему су урађена три важна задатака: 1) израђен је сајт Центра у оквиру постојећег сајта Филозофског факултета у Нишу, 2) урађен је елаборат о курсу српског језика „за преживљавање” и 3) објављен је електронски уџбеник намењен учењу српског језика код апсолутних почетника Serbian for Beginners проф. др Марине Јањић.

Остале активности центра током 2017. године

У току 2017. године није било посебних активности у оквиру рада Центра, чији су чланови своју пажњу усмерили на реализацију наставних активности, када је одржан убедљиво највећи број часова.

Остале активности изентра током 2018. године

Током 2018. године наставник и сарадник Центра проф. др Марина Јањић и мср Александар Новаковић учествовали су с рефератима на међународном научном скупу „Српски као страни језик у теорији и nракси IV" на Филолошком факултету у Београду, у организацији овог факултета и OEBS -а. Скуп је одржан од 26. до 28. октобра 2018. године, а изложени реферати објављени су у зборнику од међународног значаја (о чему ће више бити речи у поглављу о научним публикацијама чланова Центра).

Остале активности иентра током 2019. године

Током 2019. године представници Центра (доц. др Маја Вукић и доц. др Ивана Митић) били су предавачи на Летњој школи за српски језик као страни у Прагу, коју је организовала Катедра за јужнословенске и балканолошке студије Филозофског факултета у Прагу од 9. до 12. јула 2019. године. Школа је реализована у оквиру програма Еразмус+. 
Остале активности центра током 2020. године

Током 2020. године сарадник у Центру Александар Новаковић је са својим колегом Николом Татаром учествовао у креирању онлајн разврставајућег теста Tecm your Serbian, који представља чин осавремењивања начина организовања и реализације иницијалних тестова у настави српског као страног језика.

\section{5. Научна продукција наставника и сарадника Центра}

Научно-истраживачки рад наставника и сарадника Центра током његовог осмогодишњег постојања броји више одредница - четири уџбеника, две монографије, једну докторску дисертацију и више научних радова. Запажене резултате на пољу креирања уџбеника остварила је др Марина Јањић, редовни професор на Департману за србистику, која је 2016. године објавила уџбеник за апсолутне почетнике под називом Serbian for Beginners ${ }^{15}$, да би четири године потом објавила уџбенички комплет Српски - језик мога завичаја, састављен од три уџбеника (Кад си срећан!, О, радосне вести!, Подигни глас!) ради учења српског као завичајног језика на сва три нивоа (почетном, средњем и напредном). С обзиром на то да се методика наставе српског као завичајног као научна дисциплина успоставила под окриљем методике наставе српског као страног, ауторка је објавила и монографије које би овде требало уврстити: Српски језик за ученике у дијаспори (2015) и Методика наставе српског као завичајног језика (2018а), која је до сада имала два издања, као и поглавље у монографији Темељна методолошка питата наставе српског језика у дијаспори (2018b). Поред уџбеника и монографија, ауторка је у коауторству са Аном Мијајловић објавила рад изложен на међународном научном скупу Српски као страни језик у теорији и пракси IV „Сложена наставна контекстуализација као фактор унутрашње мотивације у настави српског језика као завичајног" (2020).

О квалитету и функционалности поменутих уџбеника у пракси писао је Александар Новаковић у својој докторској дисертацији под називом Полифункиионалност уибеничког комплета за учење српског као страног језика (2020а), као и у засебном раду објављеном у зборнику Српски као страни језик у теорији и пракси IV. Аутор закључује да је реч о првим електронским интерактивним уџбеницима за учење српског језика путем рачунара, а резултати спроведених истраживања показују да су странци изузетно задовољни њиховом функционалношћу. Бавећи се питањем уџбеника, за потребе докторске дисертације креира први електронски интерактивни уџбеник за учење српског као страног језика путем мобилних телефона под називом (Про)Говори српски!. Исти аутор је 15 Поред свог електронског издања (доступног на веб-сајту Центра), уџбеник је исте године био прилагођен и објављен у штампаном облику. 
објавио и припремио више научних радова из области методике наставе српског као страног језика: „Разврставајући тестови у настави српског језика као страног” (NOVAKOVIĆ, TATAR 2021), ,Структура лекције у уџбеницима за учење српског и енглеског језика као страног" (NOVAKOVIC 2020c), „Функционалност електронског интерактивног уџбеника Serbian for Beginners у настави српског језика као страног" (NOVAKOVIĆ 2020b), „Контрастивна анализа садржаја и дидактичке обликованости уџбеника за учење српског и енглеског језика као страног” (NOVAKOVIĆ 2019), „Дидактичко-методичка обликованост радне свеске за учење српског и енглеског језика као страног - контрастивни приступ" (NOVAKOVIĆ 2018a), „Изазови времена пред уџбеничким комплетом за учење српског језика - компаративни приступ мобилним апликацијама за учење енглеског језика" (NOVAKOVIĆ 2018b).

Питањем анализе грешака приликом усвајања српског језика као страног (и нематерњег) у оквиру Центра бавиле су се Нина Судимац и Ивана Митић. У својим двама радовима Нина Судимац се бави анализом грешака приликом усвајања српског језика као страног код студената румунске националности (SUDIMAC 2019), односно анализом фонетско-фонолошких и ортографских грешака приликом учења српског као страног језика (SUDIMAC 2020). Раније је ауторка написала рад под називом „Употреба ИКТ-а на пројекту Настава српског језика путем Скајпа за омладину из дијаспоре" (SUDIMAC 2014) у коме настоји да објасни специфичности онлајн наставе српског језика. Ивана Митић се у своме раду „Морфосинтаксичке карактеристике српског језика као нематерњег којим говоре ученици албанске националности" (2017а) бави питањем усвајања српскога као нематерњег језика, а у раду „Изрази за исказивање лепоте и лепог у српском као нематерњем језику" проучавањем овог специфичног дела лексике српског језика (2017b). У коауторству са Маријом Стефановић објављује два рада. У раду „Карактеристике српског као нематерњег језика код ученика средње школе Сезаи Сурои у Бујановцу” (2016а) проучава специфичности говора ове националне мањине, док се у раду „Употреба предлога у српском као нематерњем језику којим говоре ученици албанске националности" (2016) бави питањем усвајања морфолошког система.

\section{6. Закључак}

Оснивање Центра за српски као страни и нематерњи језик представља један од значајних тренутака у развоју студија националне филологије на југу Србије. Како је реч о првом Центру који је успостављен јужније од Београда, Филозофски факултет у Нишу и град Ниш добили су на изузетној важности, с обзиром на чињеницу да је велики број странаца који гравитира према Нишу добио прилику да учи српски језик и заслужи потребне сертификате и потврде ради испуњења личних жеља 
и пословних потреба. Стога се основна функција Центра реализује кроз разноврсне наставне и ненаставне активности: проверу знања, организацију курсева српског језика као страног, организовање округлих столова, учешће на конференцијама и пројектима, као и кроз публиковање наставних материјала и научноистраживачких радова.

Наставне активности Центра представљају најважнији сегмент његовог функционисања. У понуди има чак шест курсева за странце, при чему се деле у две велике групе: 1) индивидуалне курсеве (Индивидуални курс српског језика и Учене српског језика путем Скајпа) и 2) групне курсеве (Почетни курс, Средни курс, Напредни курс српскога језика и Курс српског језика за студенте на европском програму размене). При томе, настава се организује на свих шест нивоа, а анализа података из годишњих извештаја показује да се, сходно потребама ученика, најчешће реализује на почетном нивоу. Од оснивања 2013. године до краја 2020. године наставу у Центру је похађао укупно сто тридесет један страни држављанин, при чему највећи број долази из европских земаља, али има и оних који долазе из америчких и азијских. У оквиру наставних активности наставници и сарадници Центра организују различите врсте тестирања. Осим подразумеваног тестирања на почетку и крају курсева, једанаесторо студената, који нису похађали наставу у Центру, затражило је проверу знања ради издавања одговарајуће исправе. Ради реализације наставе користе се различити уџбеници, чијим комбиновањем наставници настоје да отклоне недостатке. Такође, ради побољшања квалитета наставе користе се и расположиви приручници из области методике наставе српског као страног језика.

Током осмогодишњег постојања Центра његови наставници и сарадници учествовали су на више пројеката (од националног и међународног значаја), семинара, конференција и округлих столова, на којима су у најбољем светлу представили своју матичну институцију и своју катедру. Резултате свога рада преточили су у четири уџбеника, две монографије, једну докторску дисертацију и десетине научних радова, што говори у прилог чињеници да се у Центру изучавању методике наставе српског као страног приступа систематично и поступно. Досадашњи резултати показују да наставници и сарадници и у будућности могу постизати одличне резултате на плану унапређења наставе, увећања броја ненаставних активности и успостављању тешње сарадње са осталим центрима у земљи и лекторатима у иностранству.

\section{Цитирана литература}

ĆOSIĆ 2004: Ćosić, Pavle. Priručnik za lektore i studente srpskog kao stranog jezika. Poznanj: WN UAM.

DRAŽIĆ 2008: Dražić, Jasmina. Minimalne leksičke i gramatičke strukture u srpskom kao stranom jeziku. Novi Sad: Filozofski fakultet, 2008. 
ĐORĐEVIĆ 2018: Đorđević, Kristina. „Udžbenici i priručnici srpskog jezika kao stranog". Lingvističke aktuelnosti, 31 (2018): 20-33.

JANJIĆ 2015: Janjić, Marina. Srpski jezik za učenike u dijaspori. Niš: OCD Proaktiv, 2015.

JANJIĆ 2016: Janjić, Marina. Serbian for Beginners. Niš: Filozofski fakultet, 2016.

JANJIĆ 2018a: Janjić, Marina. Metodika nastave srpskog kao zavičajnog jezika. Niš: Akademska srpska asocijacija, 2018.

JANJIĆ 2018b: Janjić, Marina „Temeljna metodološka pitanja nastave srpskog jezika u dijaspori, u: Srpska slavistika - kolektivna monografija, Tom II: Književnost, kultura, folklor, Pitanja slavistike, radovi srpske delegacije na XVI Međunarodnom kongresu slavista održanom u Beogradu 20-27. VIII 2018. Beograd: Savez slavističkih društava Srbije, Beograd: Čigoja štampa: 123137.

JANJIĆ 2020: Janjić, Marina. Srpski - jezik moga zavičaja. Niš: Akademska srpska asocijacija, 2020.

JANJIĆ, MIJAJLOVIĆ 2020: Janjić, Marina, Ana Mijajlović. „Složena nastavna kontekstualizacija kao faktor unutrašnje motivacije u nastavi srpskog jezika kao zavičajnog". Srpski kao strani jezik u teoriji i praksi IV (2020). Beograd: Filološki fakultet i Centar za srpski kao strani jezik, str. 283-301.

JOKANOVIĆ-MIHAJLOV 2010: Jokanović-Mihajlov, Jelica. Lektorske vežbe. Priručnik za srpski jezik kao strani. Beograd: Međunarodni slavistički centar, 2010.

KLAJN 2005: Klajn, Ivan. Gramatika srpskog jezika za strance. Beograd: Zavod za udžbenike i nastavna sredstva, 2005.

KRAJIŠNIK 1992: Krajišnik, Vesna. „Bibliografija jugoslovenskih radova o srpskohrvatskom jeziku kao stranom (1960-1990)". Živi jezici, XXXIV-XXXV/1-4 (1992): 184-203.

KRAJIŠNIK 1998: Krajišnik, Vesna. Naučimo padeže. Priručnik za srpski jezik kao strani. Beograd: Foto Futura, 1998.

KRAJIŠNIK 2014: Krajišnik, Vesna. „Lektorati srpskog jezika“, Zbornik Instituta za srpski jezik SANU II Srpski jezik i aktuelna pitanja jezičke politike. Beograd, 2014: 217-225.

KRAJIŠNIK 2016: Krajišnik, Vesna. „Neka pitanja iz metodike nastave srpskog kao stranog jezika”. Srpski kao strani jezik u teoriji i praksi III (tematski zbornik radova). Beograd: Filološki fakultet: 7-26.

KRAJIŠNIK 2016: Krajišnik, Vesna. Leksički pristup srpskom kao stranom. Beograd: Filološki fakultet, 2016.

KRAJIŠNIK, MARINKOVIĆ 2002: Krajišnik, Vesna, Nebojša Marinković. „O aktivnostima Centra za srpski kao strani jezik na Filološkom fakultetu u Beogradu”. Naučni sastanak slavista u Vukove dane, 30/1 (2002): 263-266.

KRAJIŠNIK, MARINKOVIĆ 2009: Krajišnik, Vesna, Nebojša Marinković. Testovi za polaganje srpskog kao stranog. Filološki fakultet, Beograd, 2009.

MITIĆ 2017a: Mitić, Ivana. „Morfosintaksičke karakteristike srpskog jezika kao nematernjeg kojim govore učenici albanske nacionalnosti”, Filolog, časopis za jezik, književnost i kulturu, godina VIII, br. 15 (2017), Univerzitet u Banjoj 
Luci, Filološki fakultet, Banja Luka: 199-210.

MITIĆ 2017b: Mitić, Ivana. „Izrazi za iskazivanje lepote i lepog u srpskom kao nematernjem jeziku”, Zbornik radova sa naučnog skupa Lepota u kulturi Bugara i Srba / Krasotata v kulturata na Brlgari i Szrbi održanog 13. maja 2016. godine na Univerzitetu „Sv. sv. Kiril i Metodiй” u Velikom Trnovu, Universitetsko izdalatelstvo „Sv. sv. Kiril i Metodiŭ”, Veliko Tъrnovo, 2017: 145-158.

MITIĆ, STEFANOVIĆ 2016a: Mitić, Ivana, Marija Stefanović. „Karakteristike srpskog kao nematernjeg jezika kod učenika srednje škole Sezai Suroi u Bujanovcu”, Philologia Mediana, br. 8 (2016), Niš: 523-537.

MITIĆ, STEFANOVIĆ 2016b: Mitić, Ivana, Marija Stefanović. „Upotreba predloga u srpskom kao nematernjem jeziku kojim govore učenici albanske nacionalnosti”, Ishodišta 2, Radovi sa II međunarodnog naučnog skupa Materijalna i duhovna kultura Srba u multietničkim sredinama i/ili perifernim oblastima održanog na Filozofskom fakultetu u Nišu 16-17. oktobra 2015. godine, Filozofski fakultet u Nišu i Savez Srba u Rumuniji (Centar za naučna istraživanja i kulturu Srba u Rumuniji), Niš / Temišvar, 2016: 95-109.

MRAZOVIĆ 2009: Mrazović, Pavica. Gramatika srpskog jezika za strance. Novi Sad: Izdavačka knjižarnica Zorana Stojanovića, Sremski Karlovci, 2009.

NOVAKOVIĆ 2018a: Novaković, Aleksandar. „Didaktičko-metodička oblikovanost radne sveske za učenje srpskog i engleskog jezika kao stranog - kontrastivni pristup”. Godišnjak za srpski jezik, br. 16 (2018): 75-94.

NOVAKOVIĆ 2018b: Novaković, Aleksandar. „Izazovi vremena pred udžbeničkim kompletom za učenje srpskog jezika - komparativni pristup mobilnim aplikacijama za učenje engleskog jezika”. Konteksti 4 (2018). Novi Sad: Filozofski fakultet: 323-340.

NOVAKOVIĆ 2019a: Novaković, Aleksandar. „Kontrastivna analiza sadržaja i didaktičke oblikovanosti udžbenika za učenje srpskog i engleskog jezika kao stranog”. Godišnjak za srpski jezik, br. 17 (2019): 65-87.

NOVAKOVIĆ 2020a: Novaković, Aleksandar. Polifunkcionalnost udžbeničkog kompleta za učenje srpskog jezika kao stranog, doktorska disertacija. Niš: Filozofski fakultet, 2020.

NOVAKOVIĆ 2020b: Novaković, Aleksandar. „Funkcionalnost elektronskog interaktivnog udžbenika Serbian for Beginners u nastavi srpskog jezika kao stranog”. Srpski kao strani jezik u teoriji i praksi IV: tematski zbornik radova (2020), Beograd: Filološki fakultet, Centar za srpski kao strani jezik: 459-474.

NOVAKOVIĆ 2020c: Novaković, Aleksandar. „Struktura lekcije u udžbenicima za učenje srpskog i engleskog jezika kao stranog”. Prilozi nastavi srpskog jezika i književnosti, 9 (2020), Banja Luka: Društvo nastavnika srpskog jezika i književnosti Republike Srpske: 81-92. http://dx.doi.org/10.7251/ PNSJK2009081N

NOVAKOVIĆ, TATAR 2021: Novaković, Aleksandar, Nikola Tatar. „Razvrstavajući testovi u nastavi srpskog jezika kao stranog”. Baština, 53 (2021), PrištinaLeposavić: Institut za srpsku kulturu: 1-15. https://doi.org/10.5937/basti- 
na31-29208

OTAŠEVIĆ 2014: Otašević, Đorđe. „Priručnici za nastavu srpskog jezika kao stranog”. Lingvističke aktuelnosti, 25 (2014): 21-30.

SUBOTIĆ, BJELAKOVIĆ 2007: Subotić, Ljiljana, Isidora Bjelaković. „Centar za srpski jezik kao strani na Filozofskom fakultetu u Novom Sadu (iskustva i perspektive)", u: Srpski kao strani jezik u teoriji i praksi (ur. Milorad Dešić). Beograd: Filološki fakultet, Centar za srpski kao strani jezik, 2007: 173-183.

SUDIMAC 2014: Sudimac, Nina. „Upotreba IKT-a na projektu Nastava srpskog jezika putem Skajpa za omladinu iz dijaspore”. Zbornik radova 7. naučno-stručnog skupa Studenti u susret nauci sa međunarodnim učešćem, 26-28. novembar, 2014, Banja Luka: 261-270.

SUDIMAC 2019: Sudimac, Nina. „Najčešće greške prilikom usvajanja srpskog jezika kao stranog kod studenata rumunske nacionalnosti”. Ishodišta 5 (2019), Temišvar: Savez Srba u Rumuniji - Centar za naučna istraživanja i kulturu u Rumuniji - Filozofski fakultet Univerziteta u Nišu: 441-455.

SUDIMAC 2020: Sudimac, Nina. „An analysis of phonetic-phonological and orthographic errors when learning Serbian as a Foreign Language". Facta Universitatis (Series Linguistics and Literature), Vol. 18 (2020): 109-118. DOI: 10.22190/FULL2001109S.

\section{Извори}

Izveštaj o radu Filozofskog fakulteta u Nišu za 2013. godinu. Niš: Filozofski fakultet. Izveštaj o radu Filozofskog fakulteta u Nišu za 2014. godinu. Niš: Filozofski fakultet. Izveštaj o radu Filozofskog fakulteta u Nišu za 2015. godinu. Niš: Filozofski fakultet. Izveštaj o radu Filozofskog fakulteta u Nišu za 2016. godinu. Niš: Filozofski fakultet. Izveštaj o radu Filozofskog fakulteta u Nišu za 2017. godinu. Niš: Filozofski fakultet. Izveštaj o radu Filozofskog fakulteta u Nišu za 2018. godinu. Niš: Filozofski fakultet. Izveštaj o radu Filozofskog fakulteta u Nišu za 2019. godinu. Niš: Filozofski fakultet. Izveštaj o radu Filozofskog fakulteta u Nišu za 2020. godinu. Niš: Filozofski fakultet.

\section{Закони и правилници}

ZAJEDNIČKI EVROPSKI OKVIR ZA UČENjE JEZIKA 2011: Common Europian Framework of Reference for Languages: Learning, Teaching, Assessment, Councile of Europe, 2011. 
Aleksandar M. Novaković

\section{ACTIVITIES OF THE CENTER FOR SERBIAN AS A FOREIGN AND NON- NATIVE LANGUAGE AT THE FACULTY OF PHILOSOPHY, UNIVERSITY OF NIŠ FROM ITS ESTABLISHMENT TO THE PRESENT DAY}

The paper presents the work of the Center for Serbian as a Foreign and NonNative Language at the Department of Serbian, Faculty of Philosophy, University of Nis. The author tries to explain the organization and functioning of the Center by analyzing the annual reports of the home institution, as well as to present the achieved results of the engaged teachers and associates in the period from its establishment in 2013 to the end of 2020. The results of the research show that the basic function of the Center is realized through various teaching and non-teaching activities: organization of Serbian as a foreign language courses and knowledge tests, organization of round tables, participation in conferences and projects and publication of teaching materials and scientific research papers. The Center offers as many as six different (individual and group) courses and three types of testing, which can be realized in the classroom or via the Internet. To date, one hundred and thirty-one students attended classes in the Center and eleven students were tested in order to receive the appropriate certificate.

Keywords: Faculty of Philosophy, Nis, Center for Serbian as a foreign and non-native language, methodology of teaching Serbian as a foreign language, teaching activities, non-teaching activities 